\title{
Screening of Fungal Strains Grown in Solid-state Culture for Production of Pectinase from Coffee Husk
}

\author{
Ngo Thi Ty Na", Phan Tai Huan ${ }^{\#}$, Nguyen Thi Bich Tram ${ }^{\#}$ \\ \# Faculty of Food Science and Technology, Nong Lam University - Ho Chi Minh City, Vietnam \\ E-mail:tyna@hcmuaf.edu.vn
}

\begin{abstract}
Eighty percent of Vietnamese coffee production can be found in Central Highlands (Tay Nguyen). This paper describes a screening of fungi strains isolated from coffee husk waste collected in Dak Lak province, Tay Nguyen, for pectinase production. It was found that 17 different fungi strains were isolated from samples of 11 coffee farms. Among them. there were only 9 trains which could hydrolyze pectin. The diameter of the hydrolysis halo around fungi colonies in Pectinase Screening Agar Medium (PSAM) was measured as an indicator to assess the pectinase activity. Phylogenetic analysis based on $28 S$ rRNA gene sequences showed that detected Rhizopus oryzae. Aspergillus oryzae and Hypocrea pseudokoningii were those giving the largest holo zones. Hypocrea pseudokoningii presented the best pectinase activity of $657.16 \mathrm{UI} / \mathrm{g}$ and was chosen for biomass production to collect enzyme. In a further study, effect of rice bran addition to coffee husk and moisture of culture medium on the spore yield of Hypocrea pseudokoningii were investigated. Using coffee husk medium with $23 \%$ rice bran addition and $65 \%$ moisture at ambient temperature, the highest spore yield of $9.2 \times 10^{8}$ spores/g was found after incubation for 168 hours. The fungi biomass product was dried at $40^{\circ} \mathrm{C}$ for 54 hours to obtain the final moisture of $12 \%$ and spore survival of $5.9 \times 10^{8}$ spores $/ \mathrm{g}$.
\end{abstract}

Keywords - Put your keywords here, keywords are separated by semi colon.

\section{INTRODUCTION}

Coffee is one of the industrial plants giving high economic value and providing significant income for farmers in many countries. At the moment Vietnam ranks second in coffee export and first in producing Robusta coffee. Central Highlands (Tay Nguyen) produces about $80 \%$ of the total coffee production in Vietnam. In rainy season coffee must be dried to prevent bad characteristics such as mildew, black, smell-lost and impurity beans. Therefore, the export price of Vietnamese coffee is usually lower than that of other countries like Brazil Colombia, Indonesia... Coffee beans can be processed by dry or wet method. The dry method discharges a large amount of untreated coffee husk causing environmental pollution. As a result, the wet processing is commonly used to enhance the quality of coffee beans. The key point of the method is the treament step of coffee husk's viscous layer. Enzyme pectinase can be used to decompose the pectin of coffe husk to support removal of this layer [1]. However the enzymatical method is not popular because of its high cost.

As a thumb rule, decomposing microorganisms require the appropriate plant substrates. Coffee husk is rich in pectin source where microorganism shows great potential in the production of pectinases [2]. Therefore, this study aimed to isolate the mold on coffee berries possesing a high pectinase activity for producing biological products from coffee husk.

\section{MATERIALS AND METHODS}

\section{A. Materials}

11 types of Robusta coffee husk were collected in different coffee farms in Daklak. Isolated and selective medium include Potatose Dextrose Agar (PDA) medium (200g potatoes, $20 \mathrm{~g}$ glucose, $20 \mathrm{~g}$ agar and $1000 \mathrm{ml}$ distill water), Potatose Dextrose Broth (PDB) medium (200g potatoes, $20 \mathrm{~g}$ glucose and $1000 \mathrm{ml}$ distilled water) and Pectinase Screening Agar (PSA) medium (10g pectin, $3 \mathrm{~g}$ $\left(\mathrm{NH}_{4}\right)_{2} \mathrm{HPO}_{4}, 2 \mathrm{~g} \mathrm{KH}_{2} \mathrm{PO}_{4}, 3 \mathrm{~g} \mathrm{~K}_{2} \mathrm{HPO}_{4}, 0.1 \mathrm{~g} \mathrm{MgSO}_{4}, 25 \mathrm{~g}$ agar and $1000 \mathrm{ml}$ distilled water). To prepare semi-solid medium, coffe husk and rice bran are sterilized at $121^{\circ} \mathrm{C}$ in 15 minutes.

\section{B. Methods}

Isolation of mold strains: Coffee husk samples were cultured on PDA medium at temperature of $30 \pm 2{ }^{\circ} \mathrm{C}$ in 48 hours. Mold were isolated by subculturing. Mold strains were identifined by phylogenetic analysis based on $28 \mathrm{~S}$ rRNA gene sequences. Screening pectinase activity: Measuring diameter of the hydrolysis halo around fungi colonies in PSA medium [3]. Spore yield determination: The 
number of spores was determined by culturing on PDA and direct counting using a microscope [4].

Optimization processing parameters for culturing molds: The molds were cultured at $30-50^{\circ} \mathrm{C}$. moisture $55-65 \%$ and $\mathrm{pH}$ from $4.0-6.0$ [3]. A central composite design (CCD) was employed to the experimental data. In this study two independent process variables are rice bran $\%\left(\mathrm{X}_{1}\right)$ and moisture $\%\left(\mathrm{X}_{2}\right)$. The selected response variables were the development of mycelium of molds $\left(\mathrm{Y}_{1}\right)$ and number of spores/gram of culture $\left(\mathrm{Y}_{2}\right)$. JMP version 6.0.7 was used to fit the quadratic response surface model to the experimental data.

\section{RESULT AND DISCUSSION}

A. The molds isolated from coffee husk possesing high pectinase activity.

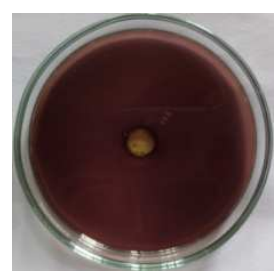

M0

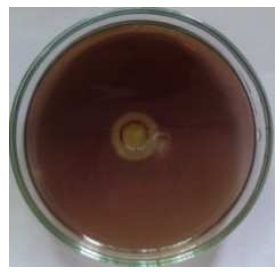

M5

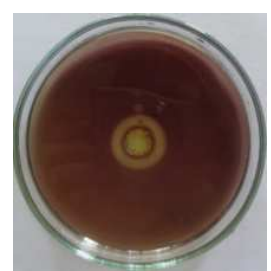

M1

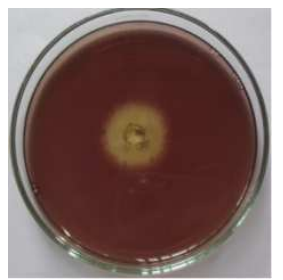

M10

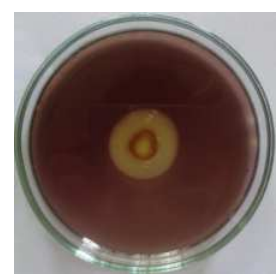

M2

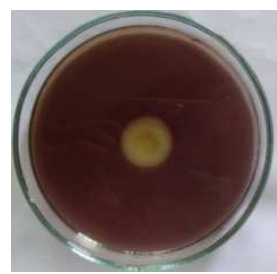

M12

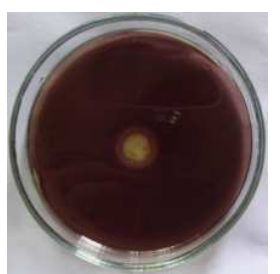

M3

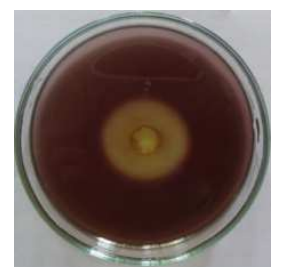

M15

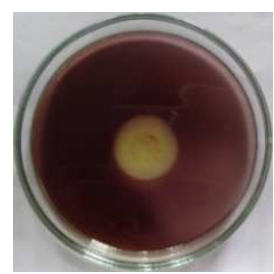

M4

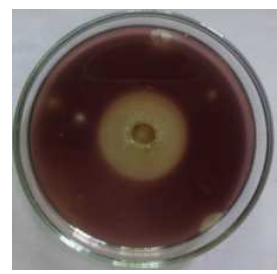

M17

Fig. 1 Diameter of halo zone on coffee husk substrate

TABLE I

COMPARISON OF PECTIN DECOMPOSING ACTIVITY OF ENZYME ISOLATED FROM DIFFERENT KINDS OF MOLDS

\begin{tabular}{|c|c|c|c|}
\hline $\begin{array}{l}\text { Strain of } \\
\text { mold }\end{array}$ & Source & $\begin{array}{l}\text { The diameter of } \\
\text { halo zone }(\mathrm{mm})\end{array}$ & Ref. \\
\hline M10 & \multirow[t]{3}{*}{ Isolated from coffe husk } & $23.67^{\mathrm{e}} \pm 0.58$ & \multirow[t]{3}{*}{ This study } \\
\hline M15 & & $26.00^{\mathrm{bc}} \pm 1.00$ & \\
\hline M17 & & $32.33^{\mathrm{a}} \pm 0.58$ & \\
\hline NM1 & \multirow{3}{*}{$\begin{array}{l}\text { Isolated from rotten } \\
\text { organe peel }\end{array}$} & $25.10^{\mathrm{cd}} \pm 0.00$ & \multirow[t]{3}{*}{ [9] } \\
\hline NM2 & & $17.10^{\mathrm{i}} \pm 0.00$ & \\
\hline NM3 & & $26.70^{\mathrm{b}} \pm 0.00$ & \\
\hline A. niger & Lomonosov University & $22.25^{\mathrm{fg}} \pm 0.44$ & \multirow[t]{5}{*}{ [10] } \\
\hline T1 & Vietnamese apple & $23.38^{\mathrm{ef}} \pm 1.15$ & \\
\hline $\mathrm{R} 1$ & Năm roi grapefruit & $25.58^{\text {bcd }} \pm 0.68$ & \\
\hline So2 & Soàn Orange & $24.33^{\mathrm{de}} \pm 0.58$ & \\
\hline N1 & Núm lemon & $23.67^{\mathrm{e}} \pm 1.15$ & \\
\hline
\end{tabular}

\section{B. Optimization processing parameters for culturing molds}

Nutrients (carbon, nitrogen and minerals), $\mathrm{pH}$ and moisture content play important role for the growth and developing of molds in the semi-solid mediun. The maxium growth of molds mycelium and the number of spores are based on the carbon source. Coffee husk contains $7.9 \%$ pectin and $5.47 \%$ reducing sugars. There is no need to add more carbon source for collecting the biomass to produce molds. To stimulate the growth of molds with vitamin B, rice bran was supplied together with coffee husk. The monitoring of moisture was established. Effecting of processing paramenters to the growth of selected mycelium molds (M17) were showed in Table 2.

This result showed that amount of of rice bran and moisture effected to the growth rate of aerial mycelium and spores. After 72 culturing hours, experiments which had low moisture and rice bran content showed the low growth rate. When increasing the moisture the growth rate is enhaced dramatically within the first 24 culturing hours. However, after 96 hours molds grew thickly because all trays had brown- green. The diffences of growth of hyphae of molds and the number of sopres were identifined after 72 hours culturing (Table 3 ). 
TABLE II

GROWTH OF M17 BY CULTURING TIME

\begin{tabular}{|c|c|c|c|c|c|c|}
\hline \multirow{2}{*}{ Exp. } & \multirow{2}{*}{ Code } & \multicolumn{2}{|c|}{ Process parameters } & \multicolumn{3}{|c|}{ Growth of mycelium $\left(\mathrm{Y}_{1}\right)$} \\
\hline & & $\begin{array}{c}\text { Rice } \\
\text { bran \% } \\
\mathrm{X}_{1}\end{array}$ & $\begin{array}{c}\text { Moisture \% } \\
\mathrm{X}_{2}\end{array}$ & 24 hours & $\begin{array}{c}48 \\
\text { hours }\end{array}$ & 72 hours \\
\hline 1 & -- & 15 & 55 & + & ++ & +++ \\
\hline 2 & $\mathrm{a} 0$ & 15 & 60 & ++ & ++++ & +++++ \\
\hline 3 & -+ & 15 & 65 & +++ & ++ & ++++++ \\
\hline 4 & $0 \mathrm{a}$ & 20 & 55 & + & +++++ & ++++ \\
\hline 5 & 00 & 20 & 60 & +++ & +++++ & ++++++ \\
\hline 6 & 00 & 20 & 60 & +++ & +++++ & ++++++ \\
\hline 7 & 00 & 20 & 60 & +++ & ++++++ & ++++++ \\
\hline 8 & $0 \mathrm{~A}$ & 20 & 65 & ++++ & ++ & +++++++ \\
\hline 9 & +- & 25 & 55 & + & +++++ & ++++ \\
\hline 10 & A0 & 25 & 60 & ++++ & +++++ & +++++++ \\
\hline 11 & ++ & 25 & 65 & ++++ & +++++ & +++++++ \\
\hline
\end{tabular}

The results in Table 3 showed that almost spores' number got highest after 168 hour of incubation. So, this incubation time was chosen to analyze effects of two process parameters $\mathrm{X}_{1}$ and $\mathrm{X}_{2}$ (Figure 2).

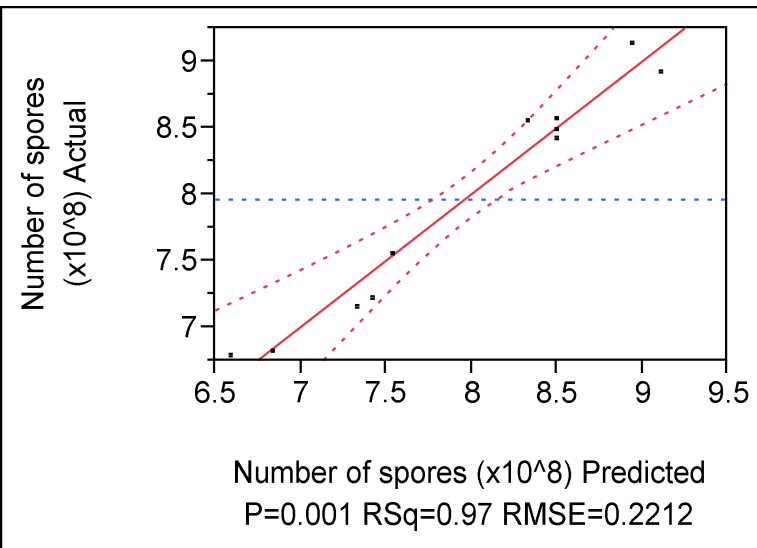

Fig. 2 Predicted vs. experimental values of different response spore number

Second order regression equation showing effects of factors on spore formation was obtained as in Equation 1. The contour plots of response surface (Figure 3) can be used to explore the changes of spores number with the changes of rice bran and moisture content.

$$
\mathrm{Y}_{2}=8.497+0.455 \mathrm{X}_{1}+0.807 \mathrm{X}_{2}+0.330 \mathrm{X}_{1} \mathrm{X}_{2}-
$$
$0.617 \mathrm{X}_{1}{ }^{2}-0.362 \mathrm{X}_{2}^{2} \quad$ (Eq.1)

TABLE III

NUMBER OF SOPRES OF M17 BY CULTURING TIME.

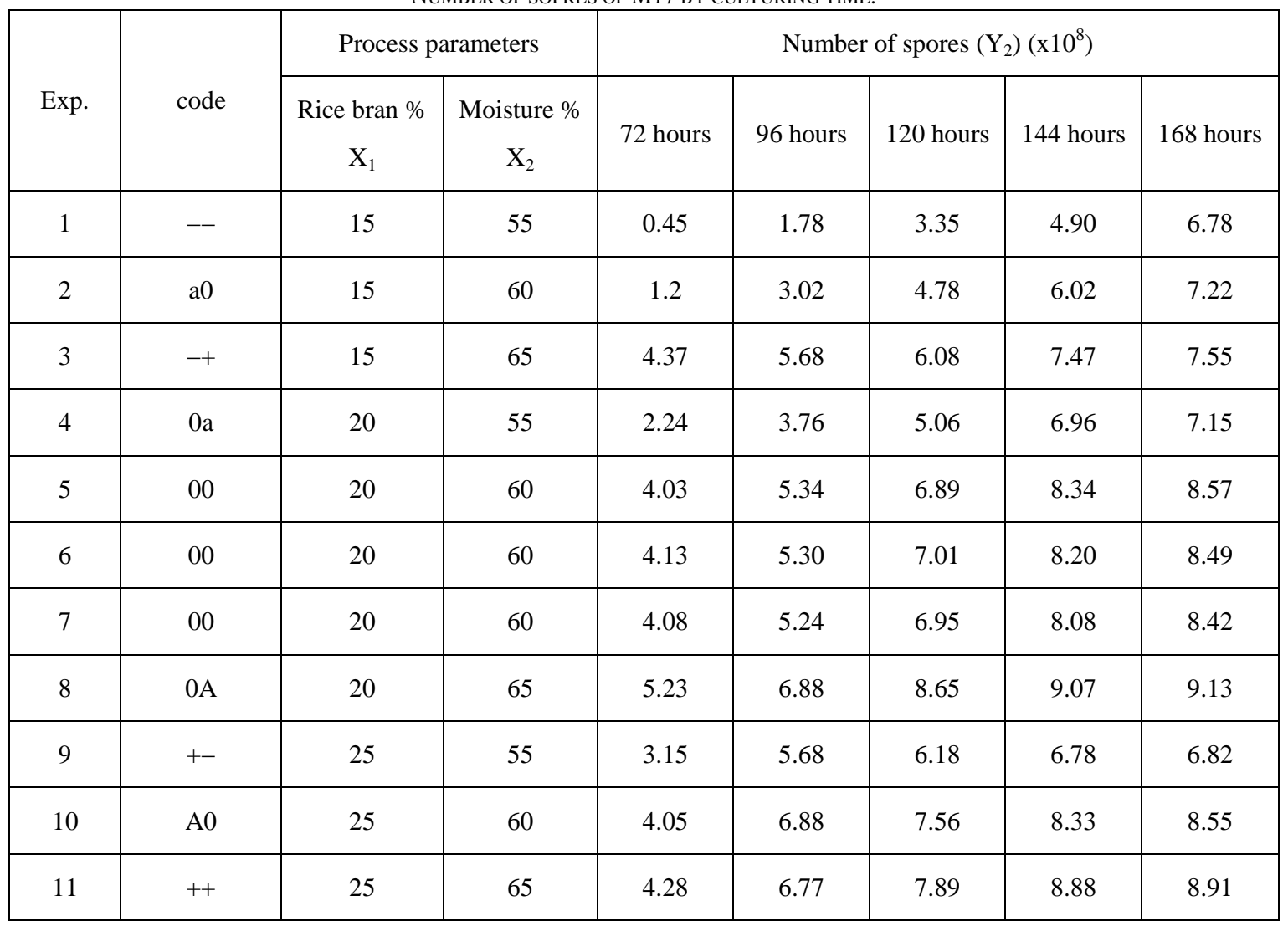




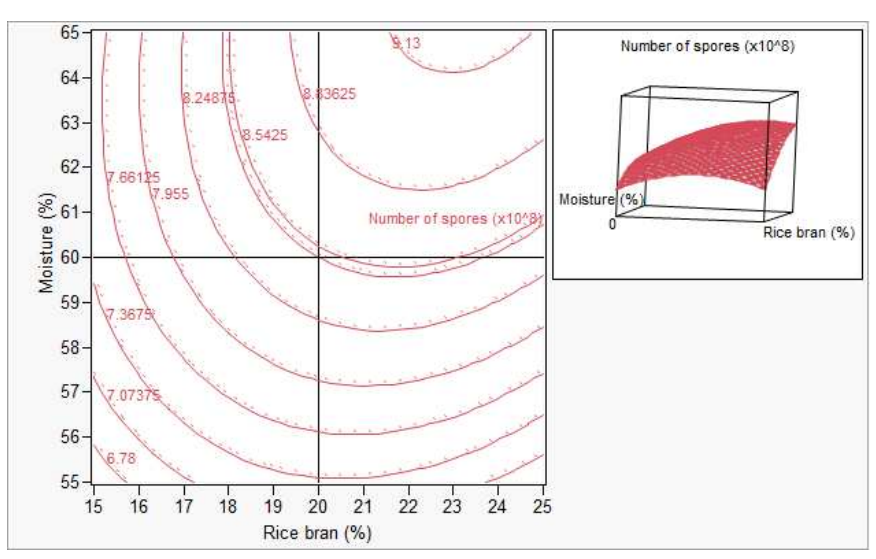

Fig. 3 Diagram of surface response

Optimum factors for spore formation were found at $23.18 \%$ of rice bran and $65 \%$ of medium's moisture content. The highest spores number was predicted as $9.19 \pm 0.41$ $\left(\mathrm{x} 10^{8}\right)$ (spores/g). Validated at the optimum condition, actual result was found with $9.21 \times 10^{8} \pm 0.2($ spore/g). This result was equivalent or even higher than the estimated value using the model. So, the processing parameters with rice bran content of $23 \%$ and moisture content of $65 \%$ were finaly selected for the M17 cultivation. Collected fungi biomass will be dried at $40^{\circ} \mathrm{C}$ in 54 hours. A procedure to produce biomass of fungi M17 is proposed as in Figure 4. Some characteristics of collected product were shown in Table 4 .

TABLE IV

CHARACTERISTICS OF COLLECTE FUNGI BIOMASS

\begin{tabular}{|l|c|}
\hline \multicolumn{1}{|c|}{ Parameters } & Result \\
\hline Himidity & $12 \%$ \\
\hline Number of viable cells & $5.9 .10^{8}$ spores/g \\
\hline
\end{tabular}

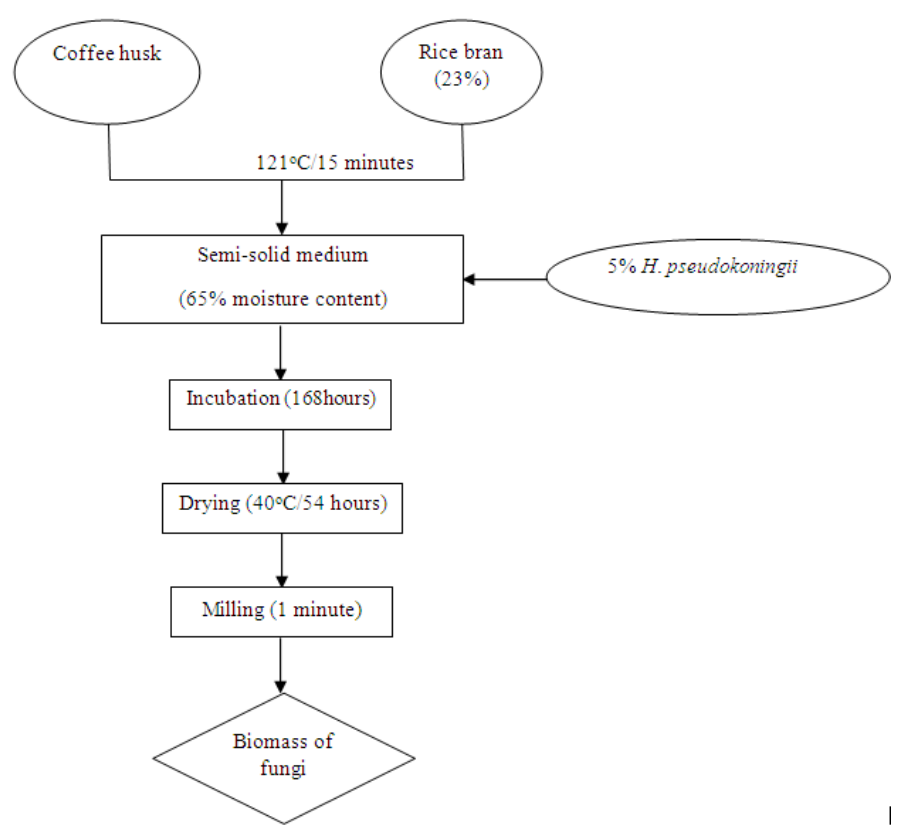

\section{CONCLUSIONS}

17 types of fungi were isolated from coffee samples grown in Daklak. Phylogenetic analysis based on 28S rRNA gene sequences showed that detected Rhizopus oryzae, Aspergillus oryzae and Hypocrea pseudokoningii were those giving the largest pectin-hydrolyse holo zones. $H$. pseudokoningii was finally selected to produce fungi biomass because of its highest pectinase activity at 657.16 UI/ $g$ of media. At optimum culturing condition, the collected biomass obtained moisture of $12 \%$ and viable mold cell density of $5.9 \times 10^{8} \mathrm{cfu} / \mathrm{g}$.

\section{REFERENCES}

[1] P. S. Murthy and M. M. Naidu M.M., "Improvement of robusta coffee fermentation with microbial enzymes," European journal of applied sciences, vol 3, pp. 130-139, 2011.

[2] E. F. Rezende, F. A Couto, J. G. Borges, D. M. Silva, L. R. Batista, "Enzymatic and toxigenic potential of fungi isolated from coffee beans," Coffee Science, Lavras 8, pp. 63 - 70, 2013.

[3] Y. Khairnar, K. V. Krishna, A. Boraste, N. Gupta, S. Trivedi, P. Patil, G. Gupta, M. Gupta, A. Jhadav, A. Mujapara, B. Joshi and D. Mishra, "Study of pectinase production in submerged fermentation using different strains of Aspergillus Niger," International journal of microbiology research, vol 1, pp. 13-17, 2009.

[4] N. V. Thanh, and Nout, M. J. R., "Dormancy, activation and viability of Rhizopus oligosporus sporangiospores,". International Journal of Food Microbiology 92, pp. 171-179, 2004.

[5] B. T. Hoa and P. V. Hung, "Optimization of nutritional composition and fermentation conditions for cellulase and pectinase production by Aspergillus oryzae using response surface methodology, International Food Research Journal, vol 20, pp. 3269-3274, 2013.

[6] T. Thangaratham and G. Manimegalai," Optimization and production of pectinase using agro waste by solid state and submerged fermentatio," International Journal of Current Microbiology and Applies Sciences, vol 3, pp. 357-365, 2014.

[7] F. Boccas, S. Roussos , M. Gutierrez, L. Serrano and G. G. Viniegra, "Production of pectinase from coffee pulp in solid state fermentation system : selection of wild fungal isolate of high potency by a simple three-step screening technique, " Journal of food science technology, vol 31, pp. 22-26, 1994.

[8] A. Khan, S. Sahay and N. Rai, "Production and optimization of pectinase enzyme using Aspergillus niger strains in solid state fermentation," Research in Biotechnology, vol 3, pp. 19-25, 2012.

[9] N. T. T. Ha, "Research on ability to synthesis a pectinase of mildew's discrete from high pectin's sustrate and use in food technology," M. Tech. thesis, Da Nang University, Việt Nam, 2011.

[10] T. T. Truc, "Isolation and screening of Aspergillus niger biosynthesize high activity pectin methylesterase," $\mathrm{PhD}$. Biotechnology. thesis, Can Tho University, Việt Nam, 2013.

Fig. 4 Production process of biomass of fungi H. pseudokoningii 